\title{
THE CONCENTRATION OF VITAMIN A IN THE BLOOD PLASMA DURING PREGNANCY 1
}

\author{
By OSCAR BODANSKY,2 J. M. LEWIS, AND MICHAEL C. C. LILLIENFELD \\ (From the Department of Pediatrics, $\cdot$ New York University College of Medicine, and the \\ Departments of Pediatrics and Obstetrics, Beth Israel Hospital, New York City)
}

(Received for publication January 18, 1943)

The effect of pregnancy upon metabolism is reflected in various ways, notably in the changes in concentration of many blood components $(1,2,3)$. The manner in which pregnancy affects the blood levels of the vitamins has been studied in detail only in the case of vitamin $C(4,5)$. In view of several recent studies on the regulation of the plasma level of vitamin A (6 to 9), it was considered of value to investigate systematically the concentration of this vitamin during the course of pregnancy.

\section{EXPERIMENTAL}

Plasma vitamin $\mathrm{A}$ and carotene determinations were carried out in 120 women at various stages of pregnancy. In 12 of these, the blood plasma was analyzed at some time during the first 2 trimesters and again in the ninth month. The subjects were advised to eat their usual diets and a record of their dietary intake, especially with regard to vitamin A-containing foods, was kept. No carotene or vitamin A concentrates were added to the diet.

The method employed for the determination of carotene and vitamin A was that of Kimble (10), with slight modifications. About 3 to $5 \mathrm{cc}$. of blood plasma were measured exactly and pipetted into a $25 \mathrm{cc}$. glass-stoppered centrifuge tube. An equal volume of 95 per cent ethyl alcohol and $8 \mathrm{cc}$. of a low-boiling purified petroleum ether were added. The resultant mixture was shaken for 10 minutes and then centrifuged. Six cc. of the supernatant petroleum ether extract were pipetted into the standard test tube of the Evelyn photoelectric colorimeter and the transmission at $440 \mathrm{~m} \mu$ read. From the observed reading, the carotene content was determined by comparison with a calibration curve prepared from the readings of known amounts of pure carotene in petroleum ether solution. The carotene was obtained from the General Biochemicals Company, Cleveland.

1 Aided by a grant from the Winthrop Chemical Company.

2 Captain, Medical Corps, Medical Department Research Laboratory, Edgewood Arsenal, Maryland.
The petroleum ether was evaporated in a water bath at a temperature not higher than $70^{\circ} \mathrm{C}$., a stream of nitrogen being passed over the liquid during evaporation. The oily residue was dissolved in $0.6 \mathrm{cc}$. of chloroform and $5.4 \mathrm{cc}$. of a 25 per cent solution of antimony chloride in chloroform were added. The maximum intensity of the resulting blue solution was measured at $620 \mathrm{m \mu}$ in the Evelyn photoelectric colorimeter. The reading was translated into biologic (International or U. S. P.) units, by referring to a calibration curve obtained with a sample of halibut liver oil of known biologic potency. Since carotene also gives a blue reaction with antimony chloride, the vitamin A content of the plasma was calculated after subtracting the blue value for carotene.

\section{RESULTS}

The averages of the concentrations of plasma carotene and vitamin $\mathrm{A}$ at monthly intervals during pregnancy are shown in Table I. The average

TABLE I

Concentration of plasma carotene and plasma vitamin $A$ during pregnancy

\begin{tabular}{|c|c|c|c|c|c|}
\hline \multirow{2}{*}{$\begin{array}{c}\text { Duration } \\
\text { of } \\
\text { preg- } \\
\text { nancy }\end{array}$} & \multirow{2}{*}{$\begin{array}{l}\text { Number } \\
\text { of } \\
\text { determi- } \\
\text { nations }\end{array}$} & \multicolumn{2}{|c|}{$\begin{array}{c}\text { Plasma concentration } \\
\text { of carotene }\end{array}$} & \multicolumn{2}{|c|}{$\begin{array}{l}\text { Plasma concentration } \\
\text { of vitamin A }\end{array}$} \\
\hline & & Average & Range & Average & Range \\
\hline $\begin{array}{c}\text { months } \\
1 \\
2 \\
3 \\
4 \\
5 \\
6 \\
7 \\
8 \\
9\end{array}$ & $\begin{array}{r}9 \\
15 \\
11 \\
11 \\
12 \\
12 \\
8 \\
12 \\
42\end{array}$ & $\begin{array}{l}\text { gammo } \\
121 \\
97 \\
123 \\
128 \\
111 \\
136 \\
152 \\
178 \\
119\end{array}$ & $\begin{array}{l}\text { per } 100 \text { cc. } \\
85 \text { to } 173 \\
51 \text { to } 180 \\
62 \text { to } 247 \\
58 \text { to } 162 \\
53 \text { to } 198 \\
93 \text { to } 350 \\
75 \text { to } 350 \\
93 \text { to } 400 \\
13 \text { to } 350\end{array}$ & $\begin{array}{c}I . U . \\
111 \\
99 \\
110 \\
106 \\
108 \\
109 \\
106 \\
101 \\
85\end{array}$ & $\begin{array}{l}\text { er } 100 \text { cc. } \\
65 \text { to } 164 \\
67 \text { to } 133 \\
87 \text { to } 134 \\
58 \text { to } 141 \\
80 \text { to } 138 \\
72 \text { to } 171 \\
75 \text { to } 144 \\
72 \text { to } 131 \\
44 \text { to } 156\end{array}$ \\
\hline
\end{tabular}

concentration of vitamin A per $100 \mathrm{cc}$. plasma was $111 \mathrm{I}$. U. during the first month of pregnancy, 99 I. U. during the second, $110 \mathrm{I}$. U. during the third, and 106, 108, and $109 \mathrm{I}$. U. during the fourth, fifth, and sixth months, respectively. The mean value of the plasma vitamin A concentrations, in 70 cases which were 6 months pregnant or less, was 105.4 I. U. per $100 \mathrm{cc}$. (standard deviation, 23.2). The averages of the plasma vitamin A 
determinations in the seventh, eighth, and ninth months were 106,101 , and 85 I. U., respectively. The mean value of the determinations for the 62 cases in this trimester was $91.1 \mathrm{I}$. U. (standard deviation, 26.2). The difference between the mean value for the first 2 trimesters, 105.4 I. U., and that for the third trimester, $91.1 \mathrm{I}$. U., was 14.3 I. U., which is more than 3 times the standard error of the difference between the two means and hence is statistically significant.

That the level of vitamin $\mathrm{A}$ in the plasma decreases during pregnancy is also evident from a study of individual subjects. The plasma concentration of vitamin A was determined at some time during the first 6 months of pregnancy in each of 12 subjects. Another vitamin A determination was carried out in the ninth month of pregnancy. As may be seen in Table II, only 3

TABLE II

Changes in plasma vitamin $A$ and carotene levels during pregnancy

\begin{tabular}{|c|c|c|c|c|c|c|}
\hline \multirow{2}{*}{ Sub- } & \multicolumn{3}{|c|}{$\begin{array}{c}\text { Plasma vitamin } \mathbf{A} \\
\text { concentration }\end{array}$} & \multicolumn{3}{|c|}{$\begin{array}{l}\text { Plasma carotene } \\
\text { concentration }\end{array}$} \\
\hline & $\begin{array}{l}\text { At early } \\
\text { stage } \\
\text { (first } 6 \\
\text { months) }\end{array}$ & $\begin{array}{l}\text { At late } \\
\text { stage } \\
\text { (ninth } \\
\text { month) }\end{array}$ & Change & $\begin{array}{c}\text { At early } \\
\text { stage } \\
\text { (first 6 } \\
\text { months) }\end{array}$ & $\begin{array}{l}\text { At late } \\
\text { stage } \\
\text { (ninth } \\
\text { month) }\end{array}$ & Change \\
\hline $\begin{array}{l}\text { Wi } \\
\mathrm{Ch} \\
\mathrm{Si} \\
\mathrm{Kr} \\
\mathrm{Po} \\
\mathrm{Ku} \\
\mathrm{Mi} \\
\mathrm{Na} \\
\mathrm{Sc} \\
\mathrm{Tu} \\
\mathrm{Al} \\
\mathrm{De}\end{array}$ & $\begin{array}{l}I . U . p e \\
124 \\
125 \\
118 \\
80 \\
123 \\
93 \\
97 \\
129 \\
91 \\
132 \\
138 \\
118\end{array}$ & $\begin{array}{c}100 c c . \\
133 \\
131 \\
118 \\
72 \\
102 \\
70 \\
72 \\
100 \\
55 \\
82 \\
83 \\
30^{*}\end{array}$ & $\begin{array}{r}9 \\
6 \\
0 \\
-8 \\
-21 \\
-23 \\
-25 \\
-29 \\
-36 \\
-50 \\
-55 \\
-88\end{array}$ & $\begin{array}{c}\text { gamma } \\
141 \\
102 \\
108 \\
99 \\
156 \\
51 \\
148 \\
77 \\
133 \\
91 \\
131 \\
113\end{array}$ & $\begin{array}{c}100 c c . \\
240 \\
128 \\
93 \\
108 \\
205 \\
50 \\
101 \\
74 \\
91 \\
120 \\
170 \\
70^{*}\end{array}$ & $\begin{array}{r}99 \\
26 \\
-15 \\
9 \\
49 \\
-\quad 1 \\
-47 \\
-\quad 3 \\
-42 \\
29 \\
39 \\
-43\end{array}$ \\
\hline
\end{tabular}

* These values were obtained after Tables I and III had been completed and are not included in the results based on those tables.

subjects failed to show decreases in vitamin $A$; in these 3 instances, there was either no change (subject $\mathrm{Si}$ ) or only slight increases (Ch: $6 \mathrm{I}$. U., Wi : 9 I. U.). Nine of the 12 subjects exhibited a drop in the plasma vitamin A concentration during pregnancy. These decreases ranged from $8 \mathrm{I}$. U. to $88 \mathrm{I}$. U., and averaged $37 \mathrm{I}$. U.

In Table III is shown the frequency. with which the various plasma concentrations of vitamin A occurred at the different stages of pregnancy. It may be seen that the lower concentrations pre-
TABLE III

Distribution of plasma vitamin $A$ concentrations at various stages of pregnancy

\begin{tabular}{|c|c|c|c|c|c|c|c|c|c|c|}
\hline \multirow{2}{*}{$\begin{array}{c}\text { Plasma } \\
\text { vitamin A } \\
\text { concentra- } \\
\text { tions }\end{array}$} & \multirow{2}{*}{$\begin{array}{c}\text { Total } \\
\text { number } \\
\text { of } \\
\text { determi- } \\
\text { nations }\end{array}$} & \multicolumn{9}{|c|}{ Duration of pregnancy in months } \\
\hline & & 1 & 2 & 3 & 4 & $\mathbf{5}$ & 6 & 7 & 8 & 9 \\
\hline $\begin{array}{l}I . U \text {. per } \\
100 \text { cc. } \\
44 \text { to } 70 \\
71 \text { to } 90 \\
91 \text { to } 110 \\
111 \text { to } 130 \\
131 \text { to } 150 \\
151 \text { to } 190\end{array}$ & $\begin{array}{r}18 \\
33 \\
38 \\
27 \\
13 \\
3\end{array}$ & $\begin{array}{l}1 \\
0 \\
3 \\
4 \\
0 \\
1\end{array}$ & $\begin{array}{l}1 \\
3 \\
7 \\
2 \\
2 \\
0\end{array}$ & $\begin{array}{l}0 \\
2 \\
4 \\
4 \\
1 \\
0\end{array}$ & $\begin{array}{l}2 \\
1 \\
2 \\
4 \\
2 \\
0\end{array}$ & $\begin{array}{l}0 \\
2 \\
4 \\
5 \\
1 \\
0\end{array}$ & $\begin{array}{l}0 \\
4 \\
4 \\
2 \\
1 \\
1\end{array}$ & $\begin{array}{l}0 \\
3 \\
2 \\
1 \\
2 \\
0\end{array}$ & $\begin{array}{l}0 \\
4 \\
4 \\
3 \\
1 \\
0\end{array}$ & $\begin{array}{r}14 \\
14 \\
8 \\
2 \\
3 \\
1\end{array}$ \\
\hline & & 9 & 15 & 11 & 11 & 12 & 12 & 8 & 12 & 42 \\
\hline
\end{tabular}

ponderate during the last trimester, and particularly during the ninth month. Thus, of 43 values above 111 units per $100 \mathrm{cc}$., 13, or 30 per cent, occurred during the last trimester; of 38 values between 91 and 110 units, 14, or 39 per cent, were found in the last trimester. In contrast, 64 per cent of the 33 values ranging from 71 to 90 units, and 78 per cent of the 18 values below 70 units occurred during the last trimester.

Figure 1 further illustrates the distribution of the various plasma concentrations of vitamin A during the 3 trimesters. As may be seen, there is a distinct shift towards the lower vitamin $\mathrm{A}$ values in the third trimester. Thus, of 35 plasma vitamin A values determined in the first trimester, and of the same number determined in the second, 20 and 26 per cent, respectively, were below 90 I. U. per $100 \mathrm{cc}$. In contrast, of 62 determinations carried out in the third trimester, 56 per cent were below this level.

From Table I it is also apparent that the plasma carotene level increases during the latter part of pregnancy. This level did not change significantly during the first 5 months of pregnancy; the mean value during this period was 111.9 gamma per 100 cc., with a standard deviation of $\mathbf{3 7}$ gamma. However, the average values rose during the sixth, seventh, and eighth months to 136 gamma, 152 gamma, and 178 gamma, respectively. The mean value for this period taken as a whole was 145.9 gamma (standard deviation of $\mathbf{4 5}$ gamma). This value was significantly higher than the mean value, 111.9 gamma, for the first $\mathbf{5}$ months. During the ninth month, the plasma carotene level dropped, reaching an average value of 119 gamma per 100 
cc., essentially the same level as that present during the first 5 months of pregnancy. The return of the plasma carotene to normal levels in the ninth month is also reflected in the study of individual subjects (Table II). Of 12 subjects, 6 showed a decrease from the levels obtained during the first 6 months, the remainder, an increase. The average change amounted to an increase of 8 gamma per $100 \mathrm{cc}$.

It was of interest to determine whether there was any relationship between the occurrence of decreases in the concentration of plasma vitamin A during the third trimester and the level of vitamin A intake during pregnancy. The patients had been questioned with respect to the intake of the following foods: number of glasses of milk drunk daily, number of eggs consumed per week, amount of vegetables, butter, cream, and cheese eaten daily. The estimates of the intakes of these foods were obviously approximate and yielded only 4 clear records of high vitamin $\mathrm{A}$ intake, and 3 clear records of low vitamin A intake, in subjects tested during the last trimester of pregnancy. These were too few in number to attempt any correlation between the level of vitamin A intake and the plasma vitamin A concentration.

\section{DISCUSSION}

Other investigators have reported that the level of blood vitamin A decreases in pregnancy. Hirst and Shoemaker (11) determined the concentration of serum vitamin $\mathrm{A}$ in a series of 35 pregnancies and found that 40 per cent of the values were below normal range. Abt, Arons, and their collaborators (12) found that the average plasma vitamin A concentration in a series of pregnant women was 20 per cent less than the average in a comparable series of normal women. Neither Hirst and Shoemaker nor Abt, Arons, and their collaborators studied the relation between the plasma vitamin A level and the duration of pregnancy so that they were not able to state when the blood levels dropped. Our results show a significant difference between the mean values of the first 6 months and the last 3 months of pregnancy. The mean value of the last trimester was 14 per cent lower than the mean value for the first 2 trimesters.

It is of interest to consider the significance of our results in conjunction with recent investiga- tions on the regulation of the plasma level of vitamin A. Various estimates $(13,14)$ of the total vitamin A content of the normal adult liver, the chief store of vitamin $\mathrm{A}$ in the body, range from about 500,000 to $1,000,000 \mathrm{I}$. U. The fetal organism may make two kinds of demand upon this depot: storage of vitamin $\mathrm{A}$ in the fetal liver and utilization of vitamin $\mathrm{A}$ by the actively growing fetal tissues.

We have previously shown that the fetal liver during the third trimester contains considerable amounts of vitamin $\mathrm{A}$ and we have reported an average value of about $12,000 \mathrm{I}$. U. for the total store of vitamin $\mathrm{A}$ in the liver of the newborn infant (6). The deposition of 12,000 units of vitamin $A$ in the fetal liver may entail the release of several-fold that amount from the maternal liver. Though the fate of blood vitamin A, arising either from ingestion or from liver release, is not known precisely, there is evidence indicating that vitamin A is not always used up economically. For example, when large amounts are ingested, only a small fraction can be accounted for by fecal excretion, storage in the liver, and daily requirement $(15,16)$. Again, data which we have previously obtained (17), as well as those of Brenner, Brookes, and Roberts (18), indicate that, during depletion, vitamin $A$ is released from the liver of the rat in amounts much greater than that required by the animal.

The actively growing tissues of the fetus may also utilize considerable amounts of vitamin A. The basal metabolism rate increases during the latter half of pregnancy and there is general agreement that most of this increase is due to the growth of the fetus, although it may also be in part accounted for by a possible activation of the maternal endocrine glands (19). There are several indications that the utilization of vitamins is probably increased at higher metabolic levels (20, 21).

In recent studies on gastro-intestinal cancer, Abels, Rhoads, and their collaborators $(7,8,14)$ have investigated the mechanisms controlling the concentration of vitamin $\mathrm{A}$ in the blood plasma. These studies indicate that decreased absorption of the vitamin from the gastro-intestinal tract or impaired hepatic function and decreased mobilization of the vitamin from the liver may result in low plasma vitamin A levels. There is no evidence 
indicating that gastro-intestinal absorption is interfered with during pregnancy, whereas the liver appears to be more susceptible to derangement at this period. Indeed, by means of various liver function tests, departures from normal hepatic function have been demonstrated (22). It is possible, therefore, that late in pregnancy, as in gastro-intestinal cancer, there occurs an interference with the release of vitamin A from the liver.

The present work also indicates that the level of plasma carotene increases significantly in the sixth, seventh, and eighth months, but drops to a normal level in the ninth. At the present time, we have no explanation for the increase in the carotene content of the blood. Studies are in progress to define in greater detail the mechanisms underlying the decrease of plasma vitamin $\mathrm{A}$ in the third trimester and to determine whether the administration of vitamin A concentrates can prevent the decrease.

\section{SUM MARY}

1. The mean value of the plasma vitamin $A$ concentration in 70 women, 6 months pregnant or

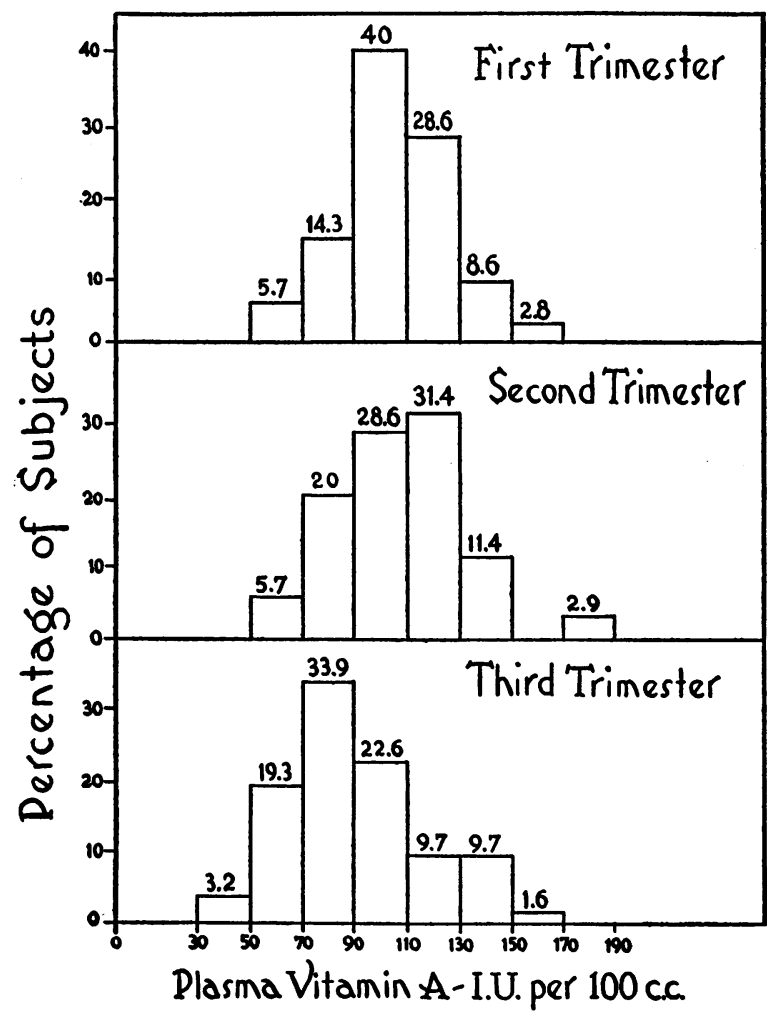

Fig. 1. Distribution of Plasma Vitamin a Concentrations During the 3 Trimesters of Pregnancy less, was 105.4 I. U. per $100 \mathrm{cc}$. (standard deviation of 23.2 units). The mean value in 62 cases in the third trimester of pregnancy was 91.1 units per $100 \mathrm{cc}$. (standard deviation of 26.2 units) and hence significantly lower than the mean value of the first 2 trimesters.

2. The mean value of the plasma carotene during the sixth, seventh, and eighth months (145.9 gamma per $100 \mathrm{cc}$.) was significantly higher than that for the first 5 months (111.9 gamma per $100 \mathrm{cc}$.).

3. The decrease in the plasma vitamin A concentration in the third trimester is probably due to storage in the fetal liver and utilization by the fetal tissues. Other possible mechanisms are discussed.

\section{BIBLIOGRAPHY}

1. Stander, H. J., Williams' Obstetrics. D. AppletonCentury Co., New York, 1941, p. 212.

2. Dieckmann, W. J., and Wegner, C. R., Blood in normal pregnancy; blood and plasma volumes. Arch. Int. Med., 1934, 53, 71.

3. Dieckmann, W. J., and Wegner, C. R., Studies of blood in normal pregnancy; conductivity, total base, chloride and acid-base equilibrium. Arch. Int. Med., 1934, 53, 527.

4. Teel, H. M., Burke, B. S., and Draper, R., Vitamin C in human pregnancy and lactation; studies during pregnancy. Am. J. Dis. Child., 1938, 56, 1004.

5. Camara, S. F., and Concepcion, I., Studies on vitamin $\mathrm{C}$; blood ascorbic acid content in pregnancy and lactation. J. Philippine M. A., 1940, 20, 407.

6. Lewis, J. M., Bodansky, O., and Haig, C., Level of vitamin $\mathrm{A}$ in the blood as an index of vitamin $\mathrm{A}$ deficiency in infants and in children. Am. J. Dis. Child., 1941, 62, 1129.

7. Abels, J. C., Gorham, A. T., Pack, G. T., and Rhoads, C. P., Metabolic studies in patients with cancer of gastro-intestinal tract; plasma vitamin A levels in patients with malignant neoplastic disease, particularly of gastro-intestinal tract. J. Clin. Invest., 1941, 20, 749.

8. Abels, J. C., et al., Metabolic studies in patients with cancer of gastro-intestinal tract; hepatic dysfunction. Ann. Int. Med., 1942, 16, 221.

9. Haig, C., and Patek, A. J. Jr., Vitamin A deficiency in Laennec's cirrhosis. Relative significance of plasma vitamin $\mathrm{A}$ and carotenoid levels and dark adaptation time. J. Clin. Invest., 1942, 21, 309.

10. Kimble, M. S., Photocolorimetric determination of vitamin A and carotene in human plasma. J. Lab. and Clin. Med., 1939, 24, 1055.

11. Hirst, J. C., and Shoemaker, R. E., Vitamin A in pregnancy; comparison of dark adaptation and 
serum tests. Am. J. Obst. and Gynec., 1941, 42, 404.

12. Abt, A. F., et al. Studies on plasma vitamin A. Part II. Relationship of plasma vitamin A to pregnancy and anemia in syphilitic patients. Quart. Bull., Northwestern Univ. M. School, 1942, 16, 245.

13. Ralli, E. P., Papper, E., Paley, K., and Bauman, E., Vitamin $\mathrm{A}$ and carotene content of human liver in normal and in diseased subjects; analysis of 116 human livers. Arch. Int. Med., 1941, 68, 102.

14. Abels, J. C., Gorham, A. T., Pack, G. T., and Rhoads, C. P., Metabolic studies in patients with gastro-intestinal cancer; hepatic concentrations of vitamin A. Proc. Soc. Exper. Biol. and Med., 1941, 48, 488.

15. Baumann, C. A., Riising, B. M., and Steenbock, H., Fat-soluble vitamins; absorption and storage of vitamin $A$ in the rat. J. Biol. Chem., 1934, 107, 705.

16. LePage, G. A., and Pett, L. B., Absorption experi- ments with vitamin A. J. Biol. Chem., 1941, 141, 747.

17. Lewis, J. M., Bodansky, O., Falk, K. G., and McGuire, G., Vitamin A requirements in the rat. The relation of vitamin $A$ intake to growth and to concentration of vitamin $\mathbf{A}$ in the blood plasma, liver and retina. J. Nutrition, 1942, 23, 351.

18. Brenner, S., Brookes, M. C. H., and Roberts, L. J., Relation of liver stores to occurrence of early signs of vitamin A deficiency in white rat. J. Nutrition, 1942, 23, 459.

19. Du Bois, E. F., Basal Metabolism in Health and Disease. Lea and Febiger, Philadelphia, 1936, p. 385.

20. Sure, B., and Buchanan, K. S., Influence of hyperthyroidism on vitamin $A$ reserves of albino rat. J. Nutrition, 1937, 13, 521.

21. Cowgill, G. R., The Vitamin B Requirement of Man. Yale University Press, New Haven, 1934, p. 65.

22. Hirsheimer, A., Hippuric acid excretion test in pregnancy. Am. J. Obst. and Gynec., 1939, 37, 363. 